Ertter, B. J. \& J. L. Reveal. 1977. A new species of Ivesia (Rosaceae) from southeastern Oregon. Madroño 24: 224-227.

Gilkey, H. M. 1956. A new Trifolium from Oregon. Madroño 13: 167-169.

Glad, J. B. 1976. Taxonomy of Mentzelia mollis and allied species (Loasaceae). Madroño 23: $283-292$.

Henderson, L. F. 1930. Some new species and varieties from Oregon. Rhodora 32: 20-28.

Keck, D. D. 1946. A revision of the Artemisia vulgaris complex in North America. Proc. Calif. Acad. Sci. 25: 421-468.

Mason, H. L. 1946. The edaphic factor in narrow endemism. II. The geographic occurrence of plants with highly restricted patterns of distribution. Madroño 8: $241-257$.

Packard, P. L. 1972. Pinus ponderosa in Malheur Co., Oregon. Madroño 21: 298.

Peck, M. E. 1945. Some interesting plants of Malheur County, Oregon. Leafl. W. Bot. 4: $177-186$

\title{
ADDENDUM
}

During the summer of $1979 \mathrm{~A}$. packardiae was found to be abundant in the Owyhee River Canyon on steep rhyolitic cliffs. In addition its range has been extended into Idaho. IDAHO: OWYHEE Co.: downstream from Couotte Hole on the South Fork of the Owyhee River, Rosentreter 1300 (Boise District of the Bureau of Land Management). OREGON: Malheur Co.: Iron Canyon, Owyhee River, Packard et al. 79-82 (CIC); across from Iron Point, Owyhee River, Packard et al. 79-87 (CIC, NY, to be distributed).

\section{CBE Style Manual}

4 th edition

This publication of the Council of Biology Editors is a guide for authors, editors, and publishers in the biological sciences. Substantially revised, this new edition contains valuable information on article planning and preparation, editorial review of the manuscript, proofreading, and indexing. It features an annotated bibliography and a greatly expanded index.

$$
\begin{aligned}
& 265 \text { pages (casebound) } \\
& \text { Postage and handling included }
\end{aligned}
$$

A $10 \%$ discount is available for orders of 10 or more copies delivered to one address. Make checks/money orders payable to "AIBS."

\section{All orders must be prepaid}

American Institute of Biological Sciences

1401 Wilson Blvd., Arlington, VA 22209 